\title{
Penerapan Metode Audiolingual (al-thariqah al-saam'iyyah al-syafawiyyah dalam Pembelajaran Maharah kalam
}

\author{
Nahdiyatul Ummah, M. Pd.I \\ almasalfin@gmail.com
}

\begin{abstract}
Abstrak
Tulisan ini akan membahas tentang penerapan Metode Audiolingual dalam pembelajaran maharah kalam. Dalam pembelajran maharah kalam sedikit siswa yang bisa mengutarakan pemikirannya secara lisan, untuk mengatasi permasalahan tersebut guru bahasa Arab dapat menerapkan metode Audiolingual. Metode Audiolingual adalah cara menyajikan pelajaran bahasa asing melalui latihan-latihan mendengarkan kemudian diikuti dengan latihan-latihan mengucapkan kata-kata dan kalimat dalam bahasa asing yang sedang dipelajari. Penelitian ini adalah penelitian kepustakaan dengan menggunakan metode analisis deskriptif. Hasil dari penelitian ini menunjukkan bahwa metode Audiolingual dalam pembelajaran maharah kalam dapat diterapkan dengan beberapa strategi pembelajaran. Metode ini menyajikan tata bahasa atau kaidah-kaidah bahasa Arab dalam bentuk pola kalimat atau dialog dengan topik seharihari, sehingga siswa tidak akan kesulitan dalam mengaplikasikan tata bahasa dalam kalimat yang akan diucapkan.
\end{abstract}

Keyword : Metode Audiolingual, al-thariqah al-saam'iyyah al-syafawiyyah , Maharah kalam

\section{A. Pendahuluan}

Pembelajaran bahasa Arab mempunyai empat keterampilan berbahasa yang harus dikuasai oleh siswa. Salah satu keterampilan berbahasa yaitu keterampilan berbicara (Maharah kalam). Maharah kalam merupakan kegiatan berbahasa yang aktif dan menuntut pengguna untuk mengungkapkan secara lisan. Berbicara adalah bagian dari kemampuan berbahasa yang aktif dan produktif. Namun, pembelajarahn maharah kalam tidaklah mudah karena kurangnya latihan lisan secara intensif.

Dalam pembelajaran maharah kalam sedikit siswa yang bisa mengutarakan pemikirannya secara lisan. Siswa kesulitan dalam mengaplikasikan tata bahasa dan terpaku dengan kaidahkaidah bahasa Arab. Selain itu siswa juga sulit menghafal kosa kata dan ungkapan-ungkapan bahasa Arab yang menjadi problematika dalam pembelajaran maharah kalam. Hal ini dapat dilihat dari sikap siswa yang kadang enggan melakukan praktek maharah kalam, karena siswa takut salah untuk menyebutkan mufrodat dan aturan apa yang harus dipakai dalam kalimat yang akan mereka ucapkan.

Untuk mengatasi permasalahan tersebut guru bahasa Arab dapat menerapkan metode Audiolingual (al-thariqah al-saam'iyyah al-syafawiyyah) dalam pembelajaran maharah kalam. Metode audiolingual adalah metode pembelajaran bahasa Arab yang lebih menekankan pada menyimak dan berbicara sebelum membaca dan menulis. Dalam pengertian lain yaitu metode pengajaran bahasa Arab yang dilakukan dengan mendengarkan bunyi kemudian mengucapkan sebagaimana mestinya (Tarigan, 1989). Metode ini dapat 
disajikan dengan menggunakan suara guru atau menggunakan media seperti kaset, video, film, slide dan lain-lain. Metode ini juga boleh menggunakan bahasa ibu sebagai pengantarnya.

Penerapan metode Audiolingual (al-thariqah al-saam'iyyah al-syafawiyyah) diharapkan dapat meningkatkan hasil belajar maharah kalam siswa yang sangat terkendala dengan minimnya kosakata dan aturan tata bahasa dengan latihan-latihan yang intensif. Dari permasalahan tersebut, peneliti tertarik untuk membahas penerapan metode audiolingual dalam meningkatkan maharah kalam siswa.

\section{B. Kajian Teori}

\section{Metode Audiolingual}

Audiolingual berasal dari dua kata yang menjadi satu bagian, yakni audio dan lingual. Audio berarti hal mendengar atau terdengar, sedangkan lingual secara bahasa bermakna hal mengenai bahasa. Metode Audiolingual adalah cara menyajikan pelajaran bahasa asing melalui latihan-latihan mendengarkan kemudian diikuti dengan latihan-latihan mengucapkan kata-kata dan kalimat dalam bahasa asing yang sedang dipelajari. (Hanani, 2016, hal. 249).

Metode audiolingual merupakan metode yang berlandaskan pada pendekatan yang memiliki beberapa asumsi. Diantaranya adalah, bahwa bahasa adalah ujaran. Asumsi lain dari metode tersebut adalah bahwa bahasa adalah kebiasaan. Suatu perilaku akan menjadi kebiasaan apabila diulang berkalikali. Oleh karena itu pengajaran bahasa harus dilakukan dengan teknik pengulangan (repetisi). (Effendi, 2009, hal. 47). Secara umum pembelajaran bahasa Arab bertujuan untuk berkomunikasi aktif dengan sesama.

Terdapat beberapa konsep dasar dalam mempelajari bahasa Asing, yaitu :

Pertama, pada dasarnya bahasa adalah percakapan yang diucapkan kemudian direkam dalam suatu tulisan. Maka pertama-tama dimulai dengan mengucapkan dan menirukan, karena jika dimulai dengan menulis dan membaca maka kemampuan dalam berbicara akan terabaikan.

Kedua, cara yang tepat dalam pembelajaran bahasa asing atau bahasa tujuan adalah membentuk kebiasaan berbahasa. Sehingga teknik yang digunakan dalam pengajarannya menggunakan teknik peniruan (muhaakah), hafalan (istidhhar), pemusatan (tarkiiz) dan latihan atau drill (tadriib).

Ketiga, belajar keterampilan berbahasa itu harus bertahap dimulai dari mendengarkan, berbicara, membaca, kemudian menulis. Lama tidaknya pembelajaran bahsa Arab ditentukan oleh kemampuan siswa dan keikutsertaanya dalam setiap jenjang.

Keempat, dalam penggunaan metode audio lingual para siswa diajari pola atau model linguistik yang memang sering digunakan oleh penutur bahasa tersebut.

Kelima, para ahli bahasa struktural menolak adanya pikiran tata bahasa semesta yang memandang adanya kaidah-kaidah bahasa secara keseluruhan. Oleh karena itu untuk memperoleh penguasaan yang baik adalah pembiasaan secara konsisten dengan jalan latihan. (Hermawan, 2014, hal. 166-169)

Jika melihat konsep dasarnya, maka ada beberapa karakteristik dalam metode ini, yaitu: 
a. Tujuan pengajarannya adalah untuk menguasai empat keterampilan berbahasa secara seimbang.

b. Urutan penyajiannya ialah dimulai dari menyimak dan berbicara baru kemudian membaca dan menulis.

c. Model kalimat bahasa asing disajikan dalam bentuk percakapan untuk dihafalkan.

d. Penguasaan pola kalimat dilakukan dengan latihan-latihan pola (pattern-practice). Latihan atau drill mengikuti urutan: stimulus > response > reinforcement.

e. Kosa kata dibatasi secara ketat dan selalu dihubungkan dengan konteks kalimat atau ungkapan, bukan sebagai kata-kata lepas yang berdiri sendiri.

f. Pelajaran menulis merupakan representasi dari pelajaran berbicara, dalam arti pelajaran menulis terdiri dari pola kalimat dan kosa kata yang sudah dipelajari secara lisan.

g. Pemakaian bahasa ibu apabila sangat diperlukan untuk penjelasan, diperbolehkan secara terbatas.

h. Apabila diperlukan pengajaran gramatika pada tahap tertentu hendaknya diajarkan secara induktif dan secara bertahap dari yang mudah ke yang sukar.

i. Pemilihan materi ditekankan pada unit dan pola yang menunjukkan adanya perbedaan struktral antara bahasa asing yang diajarkan dengan bahasa ibu pelajar.

j. Penggunaan bahan rekaman, laboratorium bahasa dan visual aids sangat diperlukan. (Munasib, hal. 81-82)

2. Maharah Kalam

Secara terminologi kalam berasal dari bahasa Arab (al-kalam) yang bermakna perkataan atau ucapan. Dilihat dari segi epistemologi, kalam adalah pengucapan bunyibunyi berbahasa Arab dengan baik dan benar sesuai dengan bunyi-bunyi yang berasal dari makhraj yang dikenal oleh para linguistik. Sedangkan mahārah kalam adalah berbicara secara terus menerus tanpa henti tanpa mengulang kosakata yang sama dengan menggunakan pengungkapan bunyi. (Kuswoyo, 2017, hal. 105)

Berbicara dalam hal ini adalah kemampuan seseorang menggunakan bahasa yang dipelajari (bahasa Arab)sebagai alat komunikasi antara satu dengan yang lain secara wajar dan lancar untuk memenuhi kebutuhannya. (Baharudin, 2015)

\section{Pembahasan}

1. Metode Audiolingual dalam Pembelajaran Maharah Kalam

Metode Audiolingual seperti yang telah dijelaskan di bab terdahulu yaitu cara penyajian pembelajaran bahasa Arab dengan latihan mendengarkan, kemudian dilanjutkan dengan latihan mengucapkan kata-kata atau kalimat dalam bahasa Arab yang sedang dipelajari. Jadi, dalam metode ini menggunakan latihan mendengar dan latihan berbicara. Metode ini dimungkinkan menggunakan bahasa ibu untuk penjelasannya agar mempermudah siswa apabila ada materi yang tidak dipahami.

Metode Audiolingual dalam pembelajaran maharah kalam dapat diterapkan dengan beberapa strategi pembelajaran, diantaranya yaitu :

a. Penghafalan dialog (dialog memorization); siswa diberikan dialog singkat untuk dihafal, kemudian mereka mempresentasikan dan memperagakan dengan mimik 
wajah. Tujuan pembelajaran ini untuk melatih siswa bereksperimen dengan unsurunsur bahasa, baik unsur verbal maupun non-verbal (misal: gestur).

b. Flashcard (kartu pengingat); guru memberikan kartu uang berisi berbagai macan kosa kata. Dan siswa mengungkapkan kata-kata lain yang mengenai kosa kata yang terdapat pada kartu tersebut.

c. Kegiatan backward build-up; merupakan kegiatan yang bertujuan agar siswa mendapatkan pengalaman atas variasi-variasi berbahasa. Siswa diberikan penggalanpenggalan kalimat, dan siswa mengulangi setiap bagian kalimat yang disampaikan oleh guru, dimulai dari kata di akhir kalimat sampai seluruh dari kalimat tersebut.

d. Latihan Berantai (chain drill); yaitu percakapan berantai di mana guru memberi sapaan atau pertanyaan kepada seorang siswa, kemudian siswa tersebut merespon, dan dan siswa tersebut memberi sapaan atau pertanyaan yang sama kepada siswa berikutnya dan begitu seterusnya.

2. Hambatan dan Solusi dalam Pembelajaran Maharah Kalam dengan Menggunakan Metode Audiolingual.

Pembelajaran maharah kalam bertujuan agar siswa mampu berkomunikasi lisan dengan baik dan wajar dengan bahasa yang sedang mereka pelajari. Secara baik dan wajar di sisni mengandung pengertian menyampaikan pesan kepada orang lain dalam sosial yang dapat diterima. Kemampuan berbicara mensyaratkan adanya pemahaman dari pembicara untuk membentuk kalimat agar mampu menyajikan kalimat yang bermakna dan dapat dipahami orang lain. Namun, masih banyak hambatan yang dialami siswa dalam pembelajaran maharah kalam seperti kurangnya latihan lisan secara intensif.

Dalam mencapai kepandaian berkomunikasi diperlukan aktivitas latihan yang mendukung dan memadai. Aktivitas seperti itu bukan perkara mudah, harus ada pemilihan metode yang tepat dalam pembelajarannya. Untuk itu penerapan metode audiolingual dirasa tepat dalam meningkatkan kemampuan berbicara siswa.

Metode audiolingual dalam pelaksanaannya terfokus pada kegiatan latihan, menghafal kosa kata, dialog, dan teks bacaan. Dasar dan prosedur pembelajaran metode ini untuk menciptakan kompetensi komunikatif siswa. Maka dari itu, dalam pembelajaran metode audiolingual siswa diharuskan mengucapkan berulang-ulang kata atau kalimat yang diperdengarkan oleh guru, latihan dan pengulangan yang dilakukan secara terus sambil menghafalkan kata atau kalimat agar siswa dapat memperluas pengetahuannya tentang kosa kata bahasa Arab.

Pembelajaran menggunakan metode audiolingual menyajikan tata bahasa atau kaidahkaidah bahasa Arab dalam bentuk pola kalimat atau dialog dengan topik sehari-hari. Penguasaan pola kalimat dilakukan dengan dengan latihan-latihan dan dilakukan repetisi dengan membuat kalimat lain yang sesuai dengn tata bahasa yang telah dipelajari.

\section{Penutup}

1. Kesimpulan

Setelah menanalisis penggunaan audio lingual dalam pembelajaran maharah kalam peneliti dapat menyimpulkan :

a. Metode Audiolingual banyak melakukan latihan dan praktek, baik dalam bentuk bacaan pendek, teks dialog, khutbah dan lain sebagainya. Metode ini menggunakan latihan mendengar dan latihan berbicara. Dalam penerapan metode ini terdapat beberapa 
strategi pembelajaran, yaitu : Penghafalan dialog (dialog memorization, Flashcard (kartu pengingat), Kegiatan backward build-up, Latihan Berantai (chain drill).

b. Pembelajaran maharah kalam bertujuan agar siswa mampu berbicara secara aktif dan produktif. Namun, dalam prakteknya terdapat beberapa hambatan yang dialami oleh siswa. Siswa kesulitan dalam berbicara menggunakan bahasa Arab karena kurangnya kosa kata yang dimiliki dan sulitnya mengaplikasikan tata bahasa ke dalam kalimat yang akan diucapkan. Untuk itu metode Audiolingual bisa menjadi soslusi dari hambatan tersebut. Dalam pembelajaran metode audiolingual siswa diharuskan latihanlatihan, ini dilakukan secara terus menerus sambil menghafalkan kata atau kalimat yang dipelajari. Metode ini menyajikan tata bahasa atau kaidah-kaidah bahasa Arab dalam bentuk pola kalimat atau dialog dengan topik sehari-hari. Penguasaan pola kalimat dilakukan dengan dengan latihan-latihan dan dilakukan repetisi dengan membuat kalimat lain yang sesuai dengn tata bahasa yang telah dipelajari. Jadi, siswa tidak akan kesulitan dalam mengaplikasikan tata bahasa dalam kalimat yang akan diucapkan karena siswa sudah terbiasa dengan struktur kalimat yang telah dipelajari.

2. Saran-saran

Untuk mencapai kesempurnaan dan tercapainya tujuan dari karya ini, peneliti merekomendasikan beberapa saran, diantaranya:

a. Mengadakan penelitian perkembangan dengan menggunakan metode penelitian lebih lanjut tentang penerapan metode audiolingual.

b. Mengimplementasikan metode audiolingual dalam skala yang lebih luas.

\section{DAFTAR PUSTAKA}

Baharudin, A. (2015, Juni 09). Albihiwa Maharah Kalam. Dipetik November 24 , 2018, dari Hiwah:

http://googleweblight.com/i?u=http://albihiwa.b;ogspot.com/2015/06/albihilwamaharahkalam.html?m\&hl=id-ID

Effendi, A. F. (2009). Metodologi Pengajaran Bahasa Arab. Malang: Misykat.

Hanani, N. (2016). Efektivitas Metode Audiolingual Dalam Pembelajaran Bahasa Arab. Realita . Hermawan, A. (2014). Metodologi Pembelajaran Bahasa Arab. Bandung: Rineka Cipta.

Kuswoyo. (2017). Konsep Dasar Pembelajaran Maharah Al-KAlam. An-Nuha .

Munasib. Metode Audiolingual Dan Penerapannya Dalam Pembelajaran Bahasa Arab. Jurnal Tarling , 1.

Tarigan, H. G. (1989). Metodologi Prngajaran Berbahasa. Jakarta: Departemen pendidikan dan kebudayaan P2LTK. 